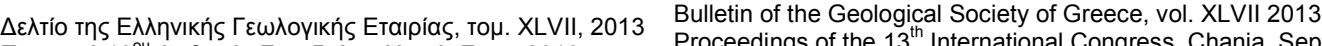

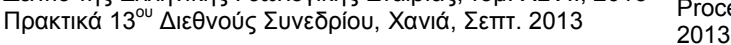

\title{
IS THE CONSTRUCTION OF A SANITARY LANDFILL ACCEPTABLE IN A KARSTIC AREA? THE CASE OF THE SANITARY LANDFILL SITE IN FOKIDA, CENTRAL GREECE
}

\author{
Soulios G. ${ }^{1}$, Mattas C. ${ }^{1}$, Kaklis T. ${ }^{1}$, Sotiriadis M. ${ }^{1}$, Voudouris K. ${ }^{1}$ and \\ Dimopoulos G. ${ }^{1}$ \\ ${ }^{1}$ Aristotle University of Thessaloniki, School of Geology, Department of Geology, Laboratory of \\ Engineering Geology and Hydrogeology \\ gsoulios@geo.auth.gr,cmattas@geo.auth.gr,kaklis@geo.auth.gr,msotiria@geo.auth.gr, \\ kvoudour@geo.auth.gr,gdimop@geo.auth.gr
}

\begin{abstract}
This paper investigates the suitability of a specific site for the construction of a sanitary landfill. The following works were performed: detailed geological mapping at a scale of 1:5,000, a geological-hydrogeological cross-section of the sanitary landfill, drilling exploration including the construction of a deep borehole for the detection of any perched aquifer, core logging and in situ permeability tests, implementation of the DRASTIC and EPIC methods to estimate the aquifer's vulnerability. Finally estimation of the total annual amount of solid waste that will be deposited into the sanitary landfill and determination of the pollution load.
\end{abstract}

Key words: karstic aquifer, vulnerability, solid waste.

\section{Пєрі́ $\eta \psi \eta$}

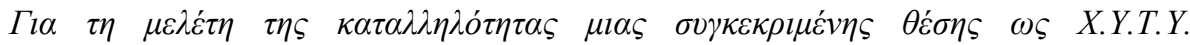

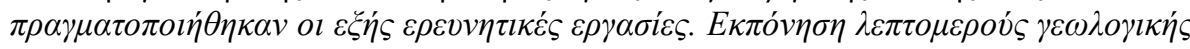

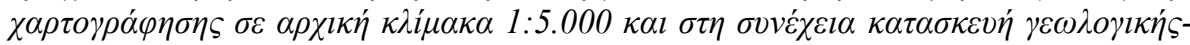

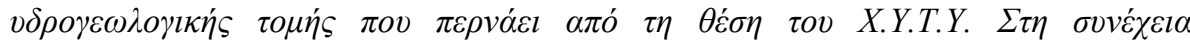

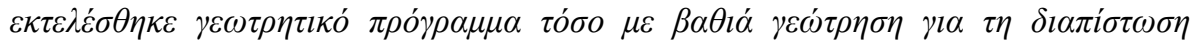

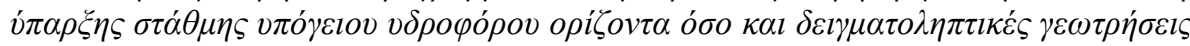

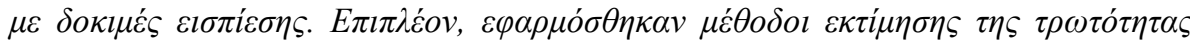

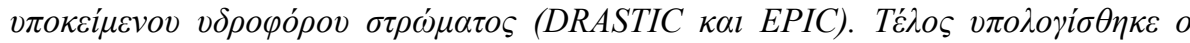

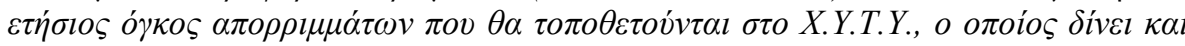

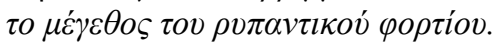

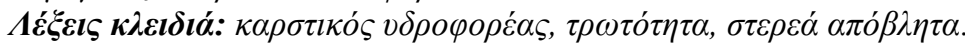

\section{Introduction}

The Association for Waste Products Management of the Prefecture of Fokida assigned to us the task of researching the suitability of the "Vartos" area as a place for the construction of a sanitary landfill. The proposed area, as shown in Figure 1, is located between Parnassos and Gkiona Mountains, at a distance approximately $3 \mathrm{~km}$ northwest of Eleonas village, which is the closest 
populated place to the study area. The site satisfies the general requirements arising from the legal framework. The whole area is mainly constituted by karst limestone formations and there is a general view among the geologists that "a priori" the karst areas are improper for the construction of sanitary landfill. We assume that this generalised conception needs to be evaluated in cases like the present one.

The siting of a landfill is a difficult, complex and protracted process requiring evaluation of many different criteria (Chang et al., 2008; Vatalis \& Manoliadis, 2002). Research on the suitability of a site for the construction of a sanitary landfill mainly comprises investigation of the transmission of pollutants underground and especially in groundwater bodies. This case is different from the case of selection of the most suitable site amongst others proposed sites which meet the basic suitability criteria (Soulios, 2006).

\section{Geological Structure}

\subsection{Geotectonic Setting}

The area belongs to the Parnassos- Giona geotectonic Unit (Renz, 1940) that has been studied in detail by Celet (1962). The northeast part of the study area forms a nappe structure upon Cenomanian limestones of the Sub-Pelagonian zone (Aubouin, 1959).

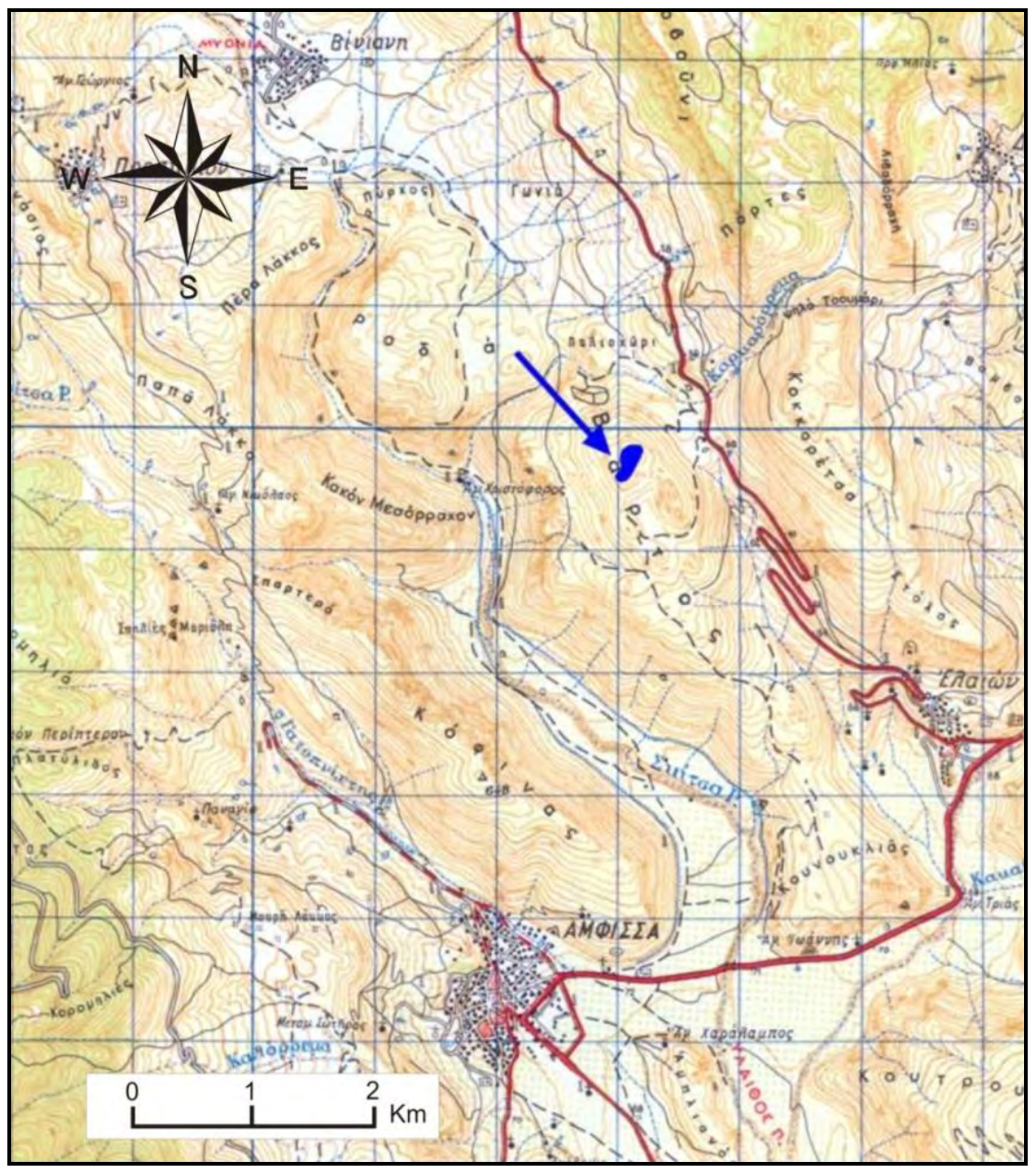

Figure 1 - Site of the studied sanitary landfill.

XLVII. No $2-772$ 


\subsection{Geological Formation}

According to the IGME (Institute of Geology and Mineral Exploration) geological map, scale 1:50,000 (Papastamatiou, 1960), the geological formations that appear around and close to the study area (Figure 2), are the following (from the most recent to the oldest):

Post-alpine formations:

- Man made soil deposits, sediments, fragmented materials

- Quaternary deposits (clays, sands, gravels)

Parnassos-Giona unit formations:

- Flysch (P.K.11): thin, laminated, in places clayed, reddish, or calcareous greenish brown or dark mudstone. The age of this formation is Palaeocene-Eocene and its thickness is around $150-250 \mathrm{~m}$.

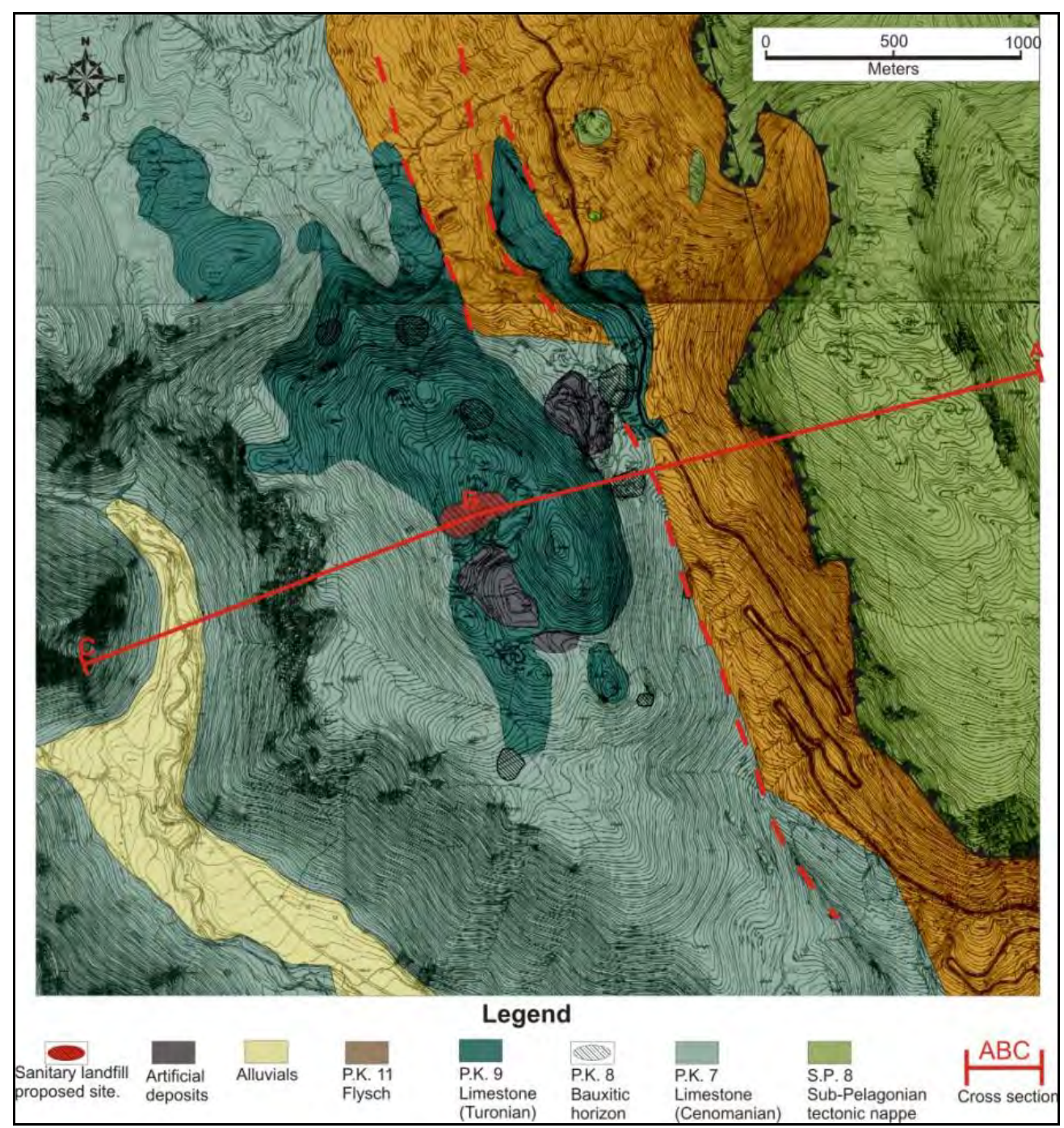

Figure 2 - Geologic map of the studied area.

- Limestone (P.K. 9): variegated (grey, dark grey, sub-white), medium-bedded to thickbedded, and intensely karstified. A rich fauna of Rudistae fragments is located in this 
formation. The age of this formation is Upper Cretaceous (Turonian-Senonian) and its thickness varies between 100 and $150 \mathrm{~m}$.

- $\quad$ Bauxitic horizon (P.K.8): the upper (third) bauxitic horizon. There is no monocline or continuous presence and appearance. Its age is Cenomanian-Turonian.

Limestones (P.K.7): black, yellow-black, yellow-white, yellow-grey, and marly by positions. Their lithology varies vertically and laterally. They are medium-bedded and massive in some places. Little to moderate karst is present in this formation. Its age is Middle-Upper Cretaceous (Cenomanian). Its thickness is more than $400-500 \mathrm{~m}$. This limestone forms the base of the sanitary landfill.

Sub-Pelagonian mass formations

- Limestone tectonic nappe consisting of fragmented whitish, blackish, mainly mediumbedded limestones (S.P.8). In places and mainly at the base it carries a clay-sandstone series. Its age is Turonian-Maestrichtian. Its thickness varies across the area, but in the study area ranges from $250 \mathrm{~m}$ to $300 \mathrm{~m}$.

\subsection{Tectonic Setting}

Regarding tectonics, folding (syncline folds, anticlinal folds) with a large radius of curvature is present. The folding axis has a direction of NNW to SSE, with or without a minor sinking angle. The tectonic of the area is characterized by large block structure in opposition to the multi folding structures which appear in neighbouring areas (Pindos mass etc).

The faults mainly have a vertical direction with vertical movement, with or without a small horizontal movement.

\section{Drilling Exploration}

\subsection{Drilling Programme}

For the detailed study of the geological basement on which the sanitary landfill will be constructed, the following works were performed:

- Drilling of a $140 \mathrm{~m}$ deep borehole for the detection of any perched or epikarstic aquifers. The water level of the main aquifer at the location where the sanitary landfill will be constructed is at a depth of $500 \mathrm{~m}$ below the ground surface.

- Logging and sampling from four boreholes with a depth up to 20-22 m with complete core sampling. The hydraulic conductivity was determined at every 3 meter intervals using the Lugeon or Maag method.

\subsection{Deep Borehole Evaluation}

The deep borehole did not encounter the aquifer. The drilling was completed in May 2009; therefore if a perched aquifer exists it would have been detected.

\subsection{Core Sampling Borehole Evaluation}

Interesting results were derived from the core logging, sampling and permeability tests, as illustrated in Figure 3 that refers to one of the boreholes. The results are as follows:

- The degree of fracturing can be characterized as usual to low and the karstification very low.

- The hydraulic conductivity ranges from $10^{-5} \mathrm{~m} / \mathrm{sec}$ to $10^{-7} \mathrm{~m} / \mathrm{sec}$, and it corresponds to geological formations that are semi-pervious to impervious. Taking into account that this coefficient corresponds to the horizontal conductivity, that is, the one that is parallel to the layering, it is obvious that the vertical conductivity will be significantly smaller. Therefore, the entire geological formation on which the sanitary landfill will be constructed can be considered impervious or marginally semi-pervious, that implies the diffusion of pollutants. 


\section{Hydrogeology}

\subsection{Hydro-lithology}

From a hydrolithological point of view, the geological formations are classified as follows:

- Flysch (PK11), which can be considered as an impervious formation.

- Limestones of Turonian-Senonian age (PK9), karstified and very permeable, as deduced from the field investigation.

- Limestones of Cenomanian age (PK7), which have locally moderate to low permeability or impermeability in places or along bedding, as deduced from the results of permeability tests. Locally they are marly and they are characterized by low karstification or no karstification.

- The sub-Pelagonian tectonic nappe consisting of limestone of Turonian-Maestrichtian age that is permeable. A productive aquifer is developed within this formation.

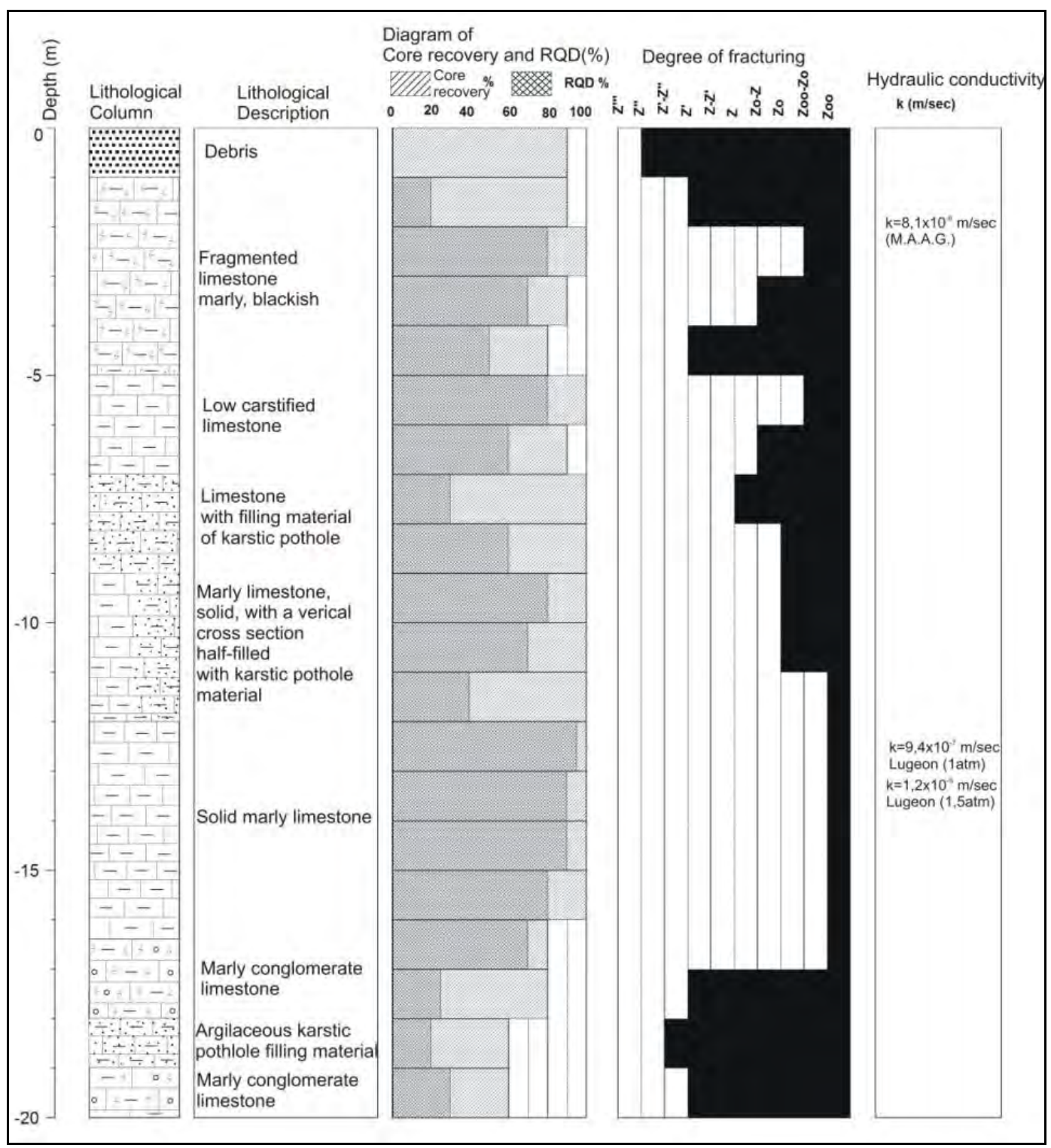

Figure 3 - Geological-geotechnical column of a constructed borehole.

$\underline{\text { XLVII. No } 2-775}$ 


\subsection{Aquifer Systems}

In Figure 4, a geological-hydrogeological section $\mathrm{ABC}$ is shown. From this section the following conclusions can be drawn.

- An aquifer system is developed within the sub-Pelagonian nappe and is discharged through Elaionas springs. The impervious basement is made up of flysch (PK11) of the Parnassos zone.

As deduced from the existing boreholes, the depth to the water table is approximately $200 \mathrm{~m}$ below the ground surface or $500 \mathrm{~m}$ below the bottom of the proposed sanitary landfill site. It is concluded that the underlying geological formation (locally semi-impervious to impervious) may eliminate the risk of pollution from the sanitary landfill.

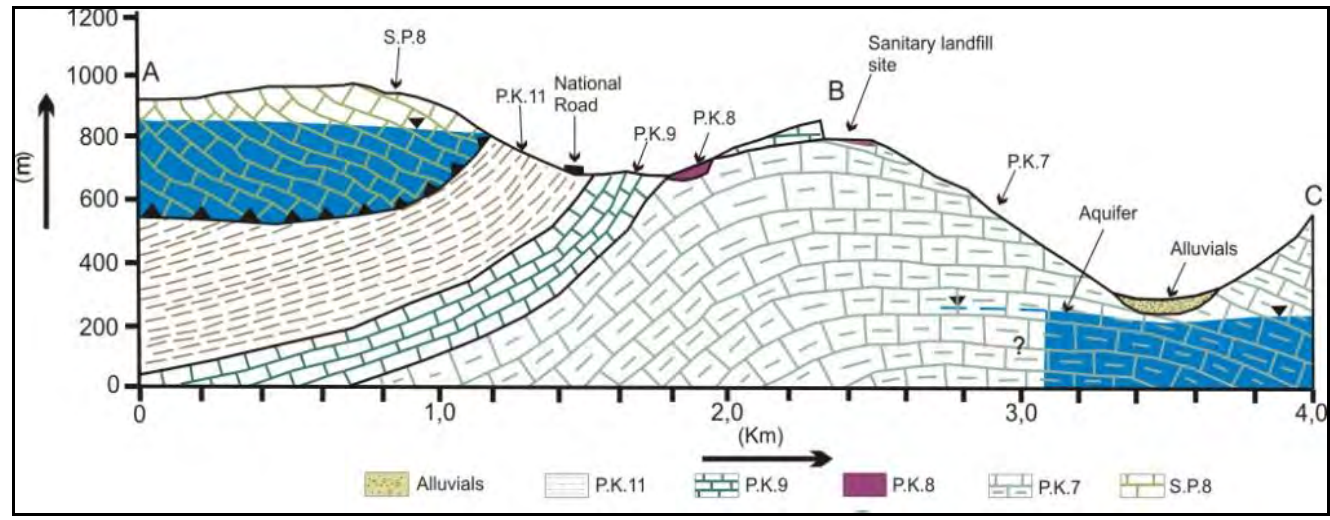

Figure 4-Indicative geological cross section (symbols as shown in Figure 2).

\section{Vulnerability Assessment}

\subsection{Karstic Aquifer Vulnerability Assessment Methods}

The degree of aquifers protection against pollution from human activities is expressed by vulnerability. In order to assess the vulnerability, many methods have been developed, each of which uses different numbers of parameters. In this work two methods (DRASTIC, EPIC) of intrinsic vulnerability were applied. The application of these methods has led to the design of vulnerability maps, which are useful tools for groundwater protection and land use planning (Panagopoulos et al., 2009; Voudouris et al., 2010; Kazakis \& Voudouris, 2011).

\subsection{DRASTIC Method}

DRASTIC (Aller et al., 1987) is a method for "any type of aquifer" that has some limitations in application to karstic aquifers (Polemio et al., 2009). The higher the DRASTIC Index (DI), the greater the groundwater pollution potential or the aquifer's vulnerability (Doerfliger et al., 1999). The DI values range from 23 (absolutely not vulnerable) to 230 (absolutely vulnerable). Based on the results, the DI value for the proposed sanitary landfill site is 102 , indicating low to moderate vulnerability.

\subsection{EPIC Method}

The EPIC method was designed to be applied to karstic aquifers and takes into consideration four karst attributes (Gogu \& Dessargues, 2000): epikarst, protective cover, infiltration conditions, and karst network. Based on the results of the application of the EPIC method, the protection factor in the proposed sanitary landfill site was estimated to be 29 , indicating low vulnerability, similar to the result of the DRASTIC method. 
It is concluded that the aquifer system below the proposed sanitary landfill site has low to moderate vulnerability and for this reason there will be no pollution risk from the construction of the particular sanitary landfill to either groundwater or surface water due to the absence of torrents in the wider region.

\section{Solid Waste Production in Fokida Prefecture - Sanitary Landfill Technical Standards}

\subsection{Population of Fokida Prefecture}

According to the 2001 census, the population of Fokida Prefecture, (except of the Municipality of Efpalinio, which is not under the jurisdiction of the Association for Waste Products Management), is 42,000 inhabitants. $25 \%$ of them do not reside permanently in Fokida. However, during the summer, the population increases due to tourism. The equivalent population is estimated to be 40,000-42,000 inhabitants.

\subsection{Waste Production}

According to a study of this specific area (Sanozidou, 2008), the annual solid waste amount (except for Efpalinio) is estimated to be 17,658 tons. Based on data provided by the Association for Waste Products Management, this amounts to 16,994 tons. The waste production in Fokida is assumed to be, $1.1 \mathrm{~kg} /$ person per day (according to the statistical mean of Greece) and the annual amount is estimated to approximately 17,000 tons. Taking into account a population increase in the following 10-20 years, the total annual amount will reach 20,000 tons, assuming that the recorded economic recession in our country during the last five years does not affect the production of solid waste.

\subsection{Waste Composition}

There are many published papers regarding the composition of the solid waste (e.g. Tchobanoglous et al., 1993; Soulios, 2006; Voudouris, 2009). In this paper we accept that the most representative composition is the one mentioned in the Joint Ministerial Decree 50910724/2003, according to which $70 \%$ of the waste is recyclable after sorting, while this percentage decreases to $50 \%$ if the sorting takes place at household level.

\subsection{Technical Standards}

The technical standards for sanitary landfills were established by the Joint Ministerial Decree (J.M.C.) 114218 (Official Government Gazette 10116B'/17-11-1997) and Ministerial Decree 29407/3508 (Official Government Gazette 1572B'/16-12-2002). Nevertheless, the placement of a natural clay layer is suggested for additional environmental protection.

Based on the above, the annual amount of waste that will arrive at the sanitary landfill will be 10,000 tons at most and probably less. This amount determines the pollution load and the environmental risk of the sanitary landfill under study, which is proportionally very small, compared, for example, to Mavrorachi landfill (Thessaloniki Prefecture), which receives 400,000 tons annually (Soulios 2006).

\section{Conclusions}

The geological basement at the sanitary landfill site consists of marly limestones, characterized by low karstification, and hydraulic conductivity value ranging between $10^{-5}$ and $10^{-7} \mathrm{~m} / \mathrm{s}$. The subjacent aquifer lies at a depth of $500 \mathrm{~m}$ below the bottom of the proposed sanitary landfill. Implementation of the DRASTIC and EPIC methods indicated that the aquifer has low to moderate vulnerability to pollution. The annual solid waste weight is approximately 10,000 tons, which does not indicate a high pollution load. Finally, special construction standards (see §6.4) 
should be applied in order to eliminate any risks of pollution. Using geological-hydrogeological criteria, the specific site is considered suitable for the construction of a sanitary landfill.

\section{References}

Aller L., Bennet T., Lehr J.H., Petty RJ. and Hackett G. 1987. DRASTIC: a standardized system for evaluating groundwater pollution potential using hydrogeological setting, EPA/600/287/035. US Environmental Protection Agency, 163 pp.

Aubouin J. 1959. Contribution a l'étude géologique de la Grèce septentrionale: les confins de l' Epire et de la Thessalie, A.G.P.H., 10, 484pp.

Celet P., 1962. Contribution à l'étude géologique du Parnasse-Kiona et d'une partie des régions méridionales de la Grèce continentale, Ann. Geol. Pays Hell., 13, 446 pp.

Chang N, Parvathinathanb G. and Breden J.B. 2008. Combining GIS with fuzzy multicriteria decision making for landfill siting in a fast-growing urban region, Journal of Environmental Management 87, 139-153.

Doerfliger N., Jeannin P.Y. and Zwahlen F. 1999. Water vulnerability assessment in karst environments: a new method of defining protection areas using a multi-attribute approach and GIS tools (EPIK method), Environmental Geology 39 (2), 165-176.

Gogu R.C. and Dessargues A. 2000. Sensitivity analysis for the EPIK method of vulnerability assessment in a small karstic aquifer, S. Belgium. Hydrogeology Journal, 8, 337-345.

Kazakis N. and Voudouris K., 2011. Comparison of three applied methods of groundwater vulnerability mapping: A case study from the Florina basin, Northern Greece, Advances in the research of aquatic environment, (Eds: Lambrakis N., Stournaras G., Katsanou K.), Springer. Proc. of 9th International Conference on Hydrogeology, Kalavrita, October 5-8, 2011, 2, 359-367.

Panagopoulos G., Antonakos A. and Lambrakis N., 2005. Optimization of the DRASTIC method for groundwater vulnerability assessment via the use of simple statistical methods and GIS. Hydrogeology Journal, 14, 894-911.

Papastamatiou I., 1960. Geological mapping of Greece 1:50.000, Sheet Amfissa, I.G.M.E. Publications.

Polemio M., Casarano D. and Limoni P.P. 2009. Karstic aquifer vulnerability assessment methods and results at a test site (Apulia, southern Italy), Natural Hazards and Earth System Sciences, 9, 1461-1470.

Renz, C. 1940. Die Tectonic der Griechisen Gebirge, Mem. Acad. Athens, 8, 171 pp.

Sanozidou M. 2008. Environmental study consideration of the Fokida Prefecture Sanitary Landfill, Unpublished Technical Report submitted to the Association for waste products management of Prefecture of Fokida (in Greek)

Soulios G., 2006. General Hydrogeology, IV, University Studio Press Publications.

Tchobanoglous G., Theisen H. and Vigil S.A. 1993. Integrated solid waste management, McGraw-Hill, 978 pp.

Vatali, K. and Manoliadis O. 2002. A two-level multicriteria DSS for landfill site selection using GIS: Case study in western Macedonia Greece. Journal of Geographic Information and Decision Analysis, Vol. 6, No 1, 49-56.

Voudouris K. 2009. Environmental Hydrogeology, Thessaloniki, Tziola Publications, 460 pp (in Greek).

Voudouris K., Kazakis N., Polemio M. and Kareklas, K. 2010. Assessment of intrinsic vulnerability using DRASTIC model and GIS in the Kiti aquifer, Cyprus, European Water, 30, 13-24. 